\title{
Why Victims of Domestic Violence Still Survive Their Marriage? Preliminary Analysis of Forgiveness Dynamics Conditions
}

\author{
Afdal Afdal ${ }^{1}$, Putri Fakhrina Sari ${ }^{1}$, Miftahul Fikri ${ }^{1}$, Ifdil ${ }^{1}$, Zadrian Ardi $^{1}$ \\ ${ }^{1}$ Universitas Negeri Padang \\ *Corresponding author, e-mail: afdal@konselor.org
}

\begin{abstract}
The purpose of this study was to find out how the dynamics of forgiveness of domestic violence victims. Anything that is the reason for the victim chooses to provide forgiveness and maintain the relationship of his household. The method used in this article is the library research method. The results of this study indicate that victims of domestic violence choose to provide forgiveness because it is influenced by certain factors. This factor becomes a force of the victim to maintain his household relationship. As for some of these factors, such as the presence of children, feeling ashamed to report the treatment of their husbands, not having a job so that they depend on living fully with their husbands and considering the length of marriage that has been fostered together.
\end{abstract}

Keywords: Forgiveness, Domestic violence victim, Marriage, Guidance and Counseling

How to Cite: Afdal, A., Sari, P.F., Fikri, M., Ifdil, I., Ardi, Z. (2019). Why Victims of Domestic Violence Still Survive Their Marriage? Preliminary Analysis of Forgiveness Dynamics Conditions. International Journal of Research in Counseling and Education, 3(2), 125-130

\section{Introduction}

The purpose of building a marriage bond is to get a happy and eternal family. On the other hand, marriage is a culture and part of the human life cycle (Oktarina, Wijaya, \& Demartoto, 2015). It means it can be said marriage is a culture will become a necessity for humans and one of the cycles that become a foundation for forming a family. Based on this, it can be said that a marriage is formed from the relationship of love and affection between a pair of men, namely men and women based on the differences between the two. These differences include ways of thinking, how to solve problems, family background, differences of opinion and even differences in principles. Couples with a marriage age of 6-10 years are more likely to face the problem of difference (Saidiyah \& Julianto, 2016). This difference must be united by both so that the relationship can go in the identic direction and become the same principle that will be followed by both. Sometimes not all couples in the household can balance this difference. Things like this can trigger problems in the household, one of which is domestic violence. Domestic violence can also be triggered by the absence of children and economic problems (Setiawan, Bhima, \& Dhanardhono, 2018). Then communication in the household also supports the occurrence of violence in the household; this is like a married couple cannot communicate well the problems they face (Maisah, 2016). Of course this problem if not resolved will be a loss for several other parties. Domestic violence is one of the hot issues discussed at this time. Given the loss that will be felt by the victim is very negative. These losses are not only emotional losses but have an impact on their psychological functioning. Since 1970, cases of violence against women throughout the world have been in the public spotlight. Violence rate in Year Reports (Catahu) data on violence against women summarized by the National Commission on Violence Against Women (Komnas Perempuan) shows that West Sumatra is the highest ranking of cases of violence against women in Sumatra with the acquisition of 999 cases ( Komnas Perempuan, 2018). Violence that occurs against women regardless of income, age or education, is the main subject of bodily, sexual, 
psychological and economic violence (Zikra, 2019). Violence is a painful act by the victim who causes injury or death to another person and causes physical damage (Hidayatullah \& Argiati, 2013). Problems in the household that can trigger violence include, infidelity, finance, excessive fatigue so that they vent it at home, and so forth. Domestic violence can also occur because of the strong culture that develops in society, namely patriarchal culture. Where in this case assume that the greatest strength and power are on the side of men, and woman is weak (Hanifah, 2007). This culture is still growing in the community so that many cases of domestic violence committed by the husband and those who become victims are none other than wives. In general, the forms of violence that occur today are like, beating, harassment, adultery, assault, and rape. In this article, a form of violence carried out by husbands against wives with a form of physical violence will be included. Domestic violence cases are indeed very alarming cases, but this case rarely rises to the surface because many victims consider that domestic violence in their household is a disgrace. It is not uncommon for victims to choose silence rather than reporting this case to the authorities. Many considered by the victim such as, fear of being ridiculed, thinking of the child's life going forward, not having a job, so they have to depend on their husband and so on. Considerations like this are what the victim thinks to be able to survive by apologizing to perpetrators of domestic violence. Forgiveness is often called forgiveness. According to (Sumiati \& Sandjaja, 2013) explaining forgiveness is the act of someone's family violence to the perpetrator where the victim reduces hatred, dislike the perpetrators of domestic violence by way of arousing compassion, compassion, and removing his feelings of resentment towards the perpetrator's treatment.

\section{Method}

The method in writing this article uses a qualitative approach by applying library research methods. In this article, which is the object of research in this study, written documents such as books, magazines and previous articles concerned are taken from journals with the same theme. In order for the problems in this article to be answered, the analysis technique used is content analysis technique. What is meant by the technique is, where the researcher tries to explain why and what reasons the victim of family violence chooses to forgive to the perpetrator who has committed violence to him and how the victim gives forgiveness? The purpose is to provide an illustration that victims of domestic violence can still maintain their family relations by forgiveness to the perpetrators, but the forgiveness of victims of domestic violence is not easy to do, and they do forgiveness with certain considerations.

\section{Results and Discussion}

\section{Domestic Violence}

Fostering a household, husband and wife must be in line and support each other. Of course, in line with that it is not as easy as turning the palm of the hand, given that between husband and wife must have different views, opinions, mindsets, planning and others. This difference must be put together so that households can be nurtured properly. Sometimes this difference can destroy a household. One of the problems is family violence. Data from the United Nations (Zikra, 2019) shows that 2 out of three cases of family violence that occur throughout the world, the victims are women. At present, household violence is a serious problem among the masses, and most of it have become a culture (Jawarkar, Shemar, Wasnik, \& Chavan, 2016). One of the triggers of family violence is because many husbands and wives cannot combine the differences between the two, so that conflicts occur. Domestic violence is a problem that often occurs in household containers (Basri, S.Kasim, \& Roslan, 2018).

\section{Cause of Domestic Violence}

Every household certainly experiences a number of points where husband and wife tension such as conflicts caused by disputes, infidelity, debates and others that may occur at any time in the household. Family violence can be triggered by several conflicts as mentioned above. The cause of family violence can also be by the culprit's personality traits, such as the offender has a 
personality who is irritable and violent (Bosede \& Alokan, 2013). The other factors on the occurrence of domestic violence according to (Jayanthi, 2009) are infidelity, economic problems, patriarchal culture is a culture that is developing in the community where it still considers that men are strong and women are weak, third party interference, gambling, and difference in principle. Domestic greeting violence can also accur due to social factors, such as low social status of women, low religious beliefs so that it is easy to treat oppression of women, but it can also be influenced by stress factors namely poverty, lack of education, levels of jealousy, substance abuse and background behind the family involved in a case of domestic violence (Ely, Dulmus, \& Wodarsski, 2017).

\section{Impact of Domestic Violence}

Domestic violence certainly can have an impact on victims. The impact of family's violence on victims is very negative and can damage the dignity of victims, such as victims of arrogance, inability to concentrate, depression, anxiety disorders, difficulty sleeping, changes in appetite patterns and decreased social competence (Sumiarti \& Puspita, 2017). According to Ramadani \& Yuliani (2015) these impacts include fear of victims and other people, anxious when doing activities at home or outside the home, tired due to pain from blows, abnormalities, posttraumatic stress, and eating and sleeping disorders, which are long reaction from violence. Victims will experience bodily and severely mentally ill impacts. In the physical can be bruises in certain parts of the body and scars on the body while the psychological impact of the victim may experience depression, trauma, fear of socializing, being a closed person and moody. A person who is depressed will hamper his ability to live life and will disrupt the victim's diet and sleep which will have an impact on his health (Alizamar et al., 2018; Zikra, 2019). Wives who experience violence can have a negative impact on health, stress disorder and can even have long-term mental health consequences (Lindgren \& Renck, 2009).

\section{Forgiveness Dynamics Victims of Domestic Violence}

The pain felt by the victim certainly causes cynical emotions to the victim, such as anger, revenge and disappointment. Forgiveness presented by Worthington (1999) is defined as the replacement of pessimistic emotions in victims with other positive emotions such as empathy, sympathy, love and love for the perpetrators. Where the victim will replace his negative emotions by forgiving the victim with compassion for the perpetrator. Whereas according to Hermawan \& Widyarini (2018) forgiveness is an attempt by someon who is to someone who to restore love and trust in the relationship so that those who are hurt and who hurt can still foster good relations, including without having to damage the relationship that has been nurtured. Domestic violence can generally occur because of the absence of a child in marriage and what is most influential is family economic problem (Setiawan et al., 2018). In addition, the cause of domestic violence can also occur due to differences in principles, infidelity and patriarchal culture (Jayanthi, 2009). The patriaki culture in question is a culture that is still thickly developed in the community, which considers that the location of the greatest power and strength in the household is the husband, so that the wife only becomes a weak creature (Rofiah, 2017). Victims who choose to maintain their relationship by giving forgiveness to the perpetrators are usually caused by shame, violence cases are considered a disgrace to the family so the victim chooses not o report the case to the authorities (Nurrachmawati, Nurohma, \& Rini, 2013).

\section{Factors Affecting Forgiveness Of Domestic Violence Victims}

Forgiveness of victims to perpetrators does not just happen, of course there are several factors that are considered by the victim. That factor could be the presence of a child, the length of a household that has been fostered and so forth. According to Mccullough (2003) these factors are "empathy, attack characteristics, personality type, quality of relationship with the offender, and religiosity." Some of the factors above are factors that allow victims to forgive the perpetrators. Another factor that was put forward by Kmiec was empathy. Someone who has high empathy is more likely to be easy to give forgiveness. Empathy can make someone have the ability to understand other people, connect with other people, and treat people. The length of marriage also affects victims to provide forgiveness to the perpetrators. There are three aspects of someone 
maintaining his household, one of which is the marriage commitment (Prianto, Wulandari, \& Rahmawati, 2013). According to McCullough's theory, the forgiveness of victims of family violence is influenced by the component of commitment in the household (Mccullough et al., 1998). In addition, financial dependence can also affect victims of domestic violence to provide forgiveness to the perpetrators (E.Papalia, Olds, \& Feldman, 2009). Then the quality factor of the relationship with the offender also influences the victim to give forgiveness, high commitment in the household and high morale (Sartika \& Amalia, 2014). Most victims of domestic violence choose to give forgiveness to the offender is to maintain the peace of the child and ensure that the child protected and the victim retains shame from people's conversation if he chooses to separate from the perpetrator, thus demanding him o remain silent and forgive the offender (Lindgren \& Renck, 2009).

\section{Forgiveness Indicators}

A victim of domestic violence can be said to have apologized to the perpetrators of violence can be indicated as if he or she has been able to accept the incident or treatment of the perpetrator, not hate, anger, revenge and begin to love the perpetrator, feel comfortable interacting with the perpetrator as if nothing happened between them (Nashori, 2014). On the other hand, an indicator of someone who gives forgiveness such as believing in a predetermined fate of God, does not question and forgive the perpetrators of violence, does not have the desire to take revenge on the actions of perpetrators and always wants to repay other people's crimes with kindness (Raudatussalamah \& Susanti, 2014). According to Jampolsky (2001) there are four forgiveness indicators, namely making peace with people who hurt, eliminates anger, throw away the desire to take revenge and get rid of the attitude of maintaining distance.

Domestic violence can occur due to several factors, including improving factor's culture, the economy, the presence of third persons and a lack of understanding of religion (Afdal, 2015). Factors such as patriarchal culture, where culture still considers that men have the power and power to assume that women are weak creatures. On the other hand, economic factors influence the occurrence of family violence; lack of income in the household raises problems and can trigger household violence. While the presence of 3rd persons is also a factor that can trigger family violence in the household. When a husband is caught cheating, and his wife rebuke or dispute the presence of the third person, the husband feels displeased and uncomfortable making the husband do unwanted things such as family violence. Then the factor of lack of understanding of religion also becomes a thing that can lead to household violence occurring, where the husband does not protect his wife, while in religion, protecting the wife is the duty of the husband. Those who tend to be victims of family violence in their households are their wives and perpetrators who are husbands. Forgiveness of victims of family violence is an apology from a victim of domestic violence to perpetrators of violence. Forgiveness given by victims is not directly given when someone makes a mistake but forgiveness requires a process. The persistence of victims of family violence in marriage is influenced by many factors. The forgiveness factor of victims of family violence is empathy, attack characteristics, personality type, and relationship quality factors, and religiosity (Safitri, 2017). In line with the above opinion, it can be said that several factors that support victims for forgiveness are the existence of children, length of marriage. Victims do not have jobs so that they demand to remain in the household to be supported by their husbands and because their love and affection are still deep. Strengthened by the opinion of Fincham \& Beach (2002) the age of marriage supports a victim of domestic violence to provide forgiveness to the perpetrator. On the other hand, victims 'financial barriers can also affect victims' forgiveness to perpetrators (Conner, 2014). The form of forgiveness of a wife who experiences domestic violence against her husband is like, not revenge against her husband, eliminate feelings (anger, hatred and hurt), able to control emotions and still interact with her husband as usual. It is hoped that with this research, techniques will be developed that can increase forgiveness. Efforts that can be done by counselors for domestic violence victims are the provision of techniques to increase victim forgiveness to perpetrators. This can be done though techniques such as cognitive restructuring and biblio counseling. This is related to previous research conducted by Resmin Manik in 2017 that uses Cognitive Restructuring techniques to improve student's forgiveness and the results increase (Manik, 2017). In addition, the Bibliocounseling technique was also conducted by Triati 
Lestari Salau in 2017 with the results of student forgiveness also increasing (Salau, Wibowo, \& Loekmono, 2017). Based on the techniques that have been done by previous researchers, it can be a basis for counsellors in using these techniques to victims of domestic violence in increasing forgiveness and counsellors can also develop techniques/approaches in counseling that can help victims of domestic violence in giving forgiveness to perpetrators of violence.

\section{Conclusion}

Based on the explanation above, it can be concluded that in fostering a household, of course there are problems that must be shared. These problems are like family violence. Usually, family violence is a problem that is covered by victims, because it considers that domestic violence cases are a disgrace to the household. It is not uncommon for victims of family violence to choose to cover up the problem, so he to keep his household by continuing to receive treatment from her husband. Domestic violence victims usually experience several impacts such as injuries and bruises in certain parts of the body. Victims who can receive treatment, and their husbands are called forgiveness. Forgiveness of victims of domestic violence is usually done because the wife thinks of several factors to keep her household in check. These factors such as the existence of children, shame if other people know the problem, do not have a job, so they must depend for their lives to their husbands and remember the households that have long been fostered together.

\section{References}

Afdal. (2015). Pemanfaatan Konseling Keluarga Eksperensial untuk Penyelesaian Kasus Kekerasan dalam Rumah Tangga. Jurnal Education, 1(1), 76-79.

Alizamar, Ifdil, Fadli, R. P., Erwinda, L., Zola, N., Churnia, E., ... Rangka, I. B. (2018). The Effectiveness of Hypnotherapy in Reducing Stress Levels. Addictive Disorders \& Their Treatment. Addictive Disorders \& Their Treatment, 174), 191-195.

Basri, S.Kasim, S., \& Roslan, S. (2018). Kekerasan dalam Rumah Tangga (KDRT) yang Dialami Suami. Jurnal Pemikiran Dan Penelitian Sosiologi, 3(2), 457-466.

Bosede, F., \& Alokan, P. (2013). Domestic Violence Against Women: A Family Menace. In Annual International Interdisciplinary Conference (pp. 24-26). Nigeria.

Conner, D. H. (2014). Financial Freedom : Women , Money , and Domestic Abuse. William \& Mary Journal of Race, Gender, and Social Justice, 20(2), 339.

E.Papalia, D., Olds, S. W., \& Feldman, R. D. (2009). Human Development (Perkembangan Manusia). In Buku 2(pp. 198-201).

Ely, G. E., Dulmus, C. N., \& Wodarsski, J. S. (2017). Domestic Violence: A Literature Review Reflecting an International Crisis. International Journal of Gynecology and Obstetrics, 72), 77-91.

Fincham, F. D., \& Beach, S. R. H. (2002). Forgiveness in marriage : Implications for psychological aggression and constructive communication. Personal Relationships, 9(3), 239-251.

Hanifah, A. (2007). Permasalahan Kekerasan dalam Rumah Tangga dan Alternatif Pemecahannya. Jurnal Penelitian Dan Pengembangan Kesejahteraan Sosial, 12(3), 45-56.

Hermawan, F., \& Widyarini, N. (2018). Effect of Forgiveness, Empathy, Attacment to Marital Satisfaction in Couple Who had Betrayed. International Journal of Research Publications, 10(1).

Hidayatullah, S., \& Argiati, S. H. B. (2013). Dinamika Psikologi dan Perilaku Forgiveness Bagi Korban Kekerasan dalam Rymah Tangga. Jurnal Spirits, 4(1), 74-80.

Jampolsky, G. G. (2001). Rela Memaafkan Obat Paling Ampuh. Jakarta: Penertbit Erlangga.

Jawarkar, A. K., Shemar, H., Wasnik, V. R., \& Chavan, M. S. (2016). Domestic Violence Against Women: a Crossectional Study In Rural Area of Amravati District of Maharashtra, India. Journal of Research in Medical Sciences, 4(7), 2713-2718.

Jayanthi, E. T. (2009). Faktor-faktor Penyebab Terjadinya Kekerasan dalam Rumah Tangga Pada Survivor yang Ditangani Oleh Lembaga Sahabat Perempuan Magelang. Jurnal Dimensia, 3(2), 33-50.

Lindgren, M. S., \& Renck, B. (2009). Intimate partner violence and the leaving process : Interviews with abused women. International Journal of Qualitative Studies on Health and Well-Being, 
3(2), 113-124. http://doi.org/10.1080/17482620801945805

Maisah. (2016). RUMAH TANGGA DAN HAM : Studi atas Trend Kekerasan dalam Rumah Tangga di Provinsi Jambi. Jurnal Musawa, 15(1), 435-438.

Manik, R. (2017). Teknik Cognitive Resructuring untuk Meningkakan Kecerdasan Emosi dan Forgiveness. Jurnal Jumpa, 5(2), 67-78.

Mccullough, M. E., Fincham, F. D., \& Tsang, J. (2003). Forgiveness, Forbearance, and Time: The Temporal Unfolding of Transgression-Related Interpersonal Motivations. Ournal of Personality and Social Psychology, 84(3), 540-557. http://doi.org/10.1037/00223514.84.3.540

Mccullough, M. E., Rachal, K. C., Sandage, S. J., Worthington, E. L., Brown, S. W., \& Hight, T. L. (1998). Interpersonal Forgiving in Close Relationships: II . Theoretical Elaboration and Measurement. Journal of Personality and Social Psychology, 75(6), 1586-1603.

Nashori, F. (2014). Psikologi pemaafan. Yogyakarta: Safiria Insania Press.

Nurrachmawati, A., Nurohma, \& Rini, P. M. (2013). Potret Kesehatan Perempuan Korban Kekerasan dalam Rumah Tangga (Studi Kasus di Pusat Pelayanan Terpadu Pemberdayaan Perempuan dan Anak Kalimatan Timur). Jurnal Kesehatan Reproduksi, 3(1), 24-37.

Oktarina, L. P., Wijaya, M., \& Demartoto, A. (2015). Pemaknaan Perkawinan: Studi Kasus Pada Perempuan lajang Yang BekerjaDi Kecamatan Bulukerto Kabupaten Wonogiri. Jurnal Analisa Sosiolog, 4(1), 75-90.

Perempuan, K. (2018). Catatan Tahunan Tentang Kekerasan Terhadap Perempuan. Jakarta. Retrieved from https://www.komnasperempuan.go.id/file/pdf_file/2018/Publikasi/Catatan Tahunan Kekerasan Terhadap Perempuan 2018.pdf

Prianto, B., Wulandari, \& Rahmawati. (2013). Rendahnya Komitmen dalam Perkawinan Sebagai Sebab Perceraian. Jurnal Komunitas, 5(2), 208-218.

Ramadani, M., \& Yuliani, F. (2015). Kekerasan dalam Rumah Tangga (KDRT) Sebagai Salah Satu Isu Kesehatan Masyarakat Secara Global. Jurnal Kesehatan Masyarakat Andalas, 9(2), 80-87.

Raudatussalamah, \& Susanti, R. (2014). Pemaafam (Forgiveness) dan Psychological Wellbeing Pada Narapidana Wanitta. Jurnal Marwah, 13(2), 219-234.

Rofiah, N. (2017). Kekerasan Dalam Rumah Tangga dalam Perspektif Islam, 2(1), 31-44. http://doi.org/10.15575/jw.v2i1.829

Safitri, A. M. (2017). Proses dan Faktor yang Mempengaruhi Perilaku Memaafkan pada Remaja Broken Home. Jurnal Psikoborneo, 5(1), 152-161.

Saidiyah, S., \& Julianto, V. (2016). Problem Pernikahan dan Strategi Penyelesaian : Studi Kasus Pada Pasangan Ssuami Istri Dengan Usia Perkawinan di Bawah Sepuluh Tahun. Jurnal Psikologi Undip, 15(2), 124-133.

Salau, T. L., Wibowo, M. E., \& Loekmono, J. T. L. (2017). Pengembangan Model Bimbingan Kelompok Teknik Bibliocounseling untuk Meningkatkan Sikap Forgiveness Siswa SMA Swasta Kota Atambua. Jurnal Bimbingan Konseling, 6(2), 196-205.

Sartika, D., \& Amalia, N. F. (2014). Forgiveness in Wives Experiencing Domestic Violence. International Journal of Social Science and Humanity, 4(3), 238-241. http://doi.org/10.7763/IJSSH.2014.V4.354

Setiawan, C. N., Bhima, S. K. L., \& Dhanardhono, T. (2018). Faktor-faktor yang Memengaruhi Kejadian Kekerasan dalam Rumah Tangga dan Pelaporan pada Phak Kepolisian. Jurnal Kedokteran Diponegoro, 71), 127-139.

Sumiarti, A., \& Puspita, H. (2017). The Relationship between Domestic Violence, Social Support , and Self Esteem of Women Victims. Journal of Family Sciences, 2(2), 3444.

Sumiati, I., \& Sandjaja, S. S. (2013). Hubungan antara memaafkan dengan kematangan diri pada remaja akhir. Jurnal Noetic Psychology, 3(2), 144-162.

Worthington, E. L. \& W. N. G. (1999). The psychology of unforgiveness and forgiveness and implications for clinical practice. Journal of Social and Clinical Psychology, 18, 385-418.

Zikra, Z. (2019). Chronotherapy for Women Victims of Domestic Violence Chronotherapy untuk Wanita Korban Kekerasan dalam Rumah Tangga. In Jurnal Penelitian Pendidikan Indonesia (Vol. 5, pp. 20-23). 